NBER WORKING PAPER SERIES

\title{
THE IMPACT OF INDUSTRIAL RELATIONS LEGISLATION \\ ON BRITISH UNION DENSITY
}

\author{
Richard Freeman \\ Jeffrey Pelletier
}

Working Paper No. 3167

\author{
NATIONAL BUREAU OF ECONOMIC RESEARCH \\ 1050 Massachusetts Avenue \\ Cambridge, MA 02138 \\ November 1989
}

\begin{abstract}
We thank Allison Booth and David Blanchflower for comments and discussion and Paul Weiler for help in developing our labor law index. This paper is part of NBER's research program in Labor Studies. Any opinions expressed are those of the authors not those of the National Bureau of Economic Research.
\end{abstract}


NBER Working Paper \#3167

November 1989

THE IMPACT OF INDUSTRIAL RELATIONS LEGISLATION ON BRITISH UNION DENSITY

\section{ABSTRACT}

The unionized share of the work force changed markedly in the United Kingdom between the 1970s and 1980s. In the 1970s density rose steadily, making the United Kingdom the most heavily organized large OECD country. In the $1980 \mathrm{~s}$, by contrast, density fell by 1.4 percentage points per annum - - a faster drop than in the rapidly de-unionizing U.S. or in Japan. What explains this turnaround - the severe recession of the 1980s? Shifts in the composition of employment from unionized manufacturing to services? The Thatcher government's industrial relations legislation?

In this paper we investigate these questions with a quantitative analysis of 1945-1986 changes in British union density. In contrast to studies that concentrate on cyclical determinants of unionism (Bain and Elshiekh, Carruth and Disney, Booth (1983)) we focus on industrial relations legislation. We develop an index of the favorableness of labor laws to unionism and relate it to changes in density in time series regressions that control for inflation, unemployment, and the manufacturing share of employment, among other variables. As a further test, we develop an analogous labor law index for Ireland, whose industrial relations system is similar to the U.K.'s and which experienced a similar severe 1980 s recession but which did not pass new laws to weaken unions, and contrast changes in density between the countries with differences in industrial relations law. Our major finding is that the Thatcher government's labor laws caused much of the 1980 s fall in British union density.

We present the evidence for this claim in three stages. Section 1 lays out the facts of changing union density in the U.K. and Ireland and examines structural explanations of the U.K. changes. Section 2 discusses the 1980 s U.K. labor laws and develops an index of their likely impact on unionism. Section 3 presents our econometric analysis of the U.K. time series data.

Richard Freeman Harvard University and NBER

1050 Massachusetts Ave Cambridge, MA 02138
Jeffrey Pelletier, Research Analyst United Food \& Commercial Workers Research office $1775 \mathrm{~K}$ Street, NW Washington, DC 20006 


\section{Changes in Union Density}

While at first blush measuring the change in union density would appear to be a simple matter of obtaining relevant counts, it is more complex, for two reasans. First, because there is a range of plausible choices of numerator and denaminator in arry union density statistic. In the nmerator ane can use union membership or workers covered by collective bargaining - figures which differ because same unions do not win reagnition and because same workers reject unians even in organized workplaces. In the denominator one can use employment, or a subset thereof, or the labour force. Each measure yields a somewhat different picture of levels and changes in union representation, as Kelly (1987) has stressed. For the U.K., collective bargaining coverage exceeds the proportion of workers who are unianised, which in turn exceeds the unian proportion of the labor force because few unemployed unionists maintain membership. 1 by dividing cyclical union employment by less cyclical labour force, density based on the labour force shows greater changes over the cycle than density based on employment. Between 1979 and 1985, for example, the ratio of union membership to the labour force drapped by 11.1 points campared to a 7.8 point fall in the ratio of union membership to employment. 2 As we are concerned with secular changes in density, we concentrate on membership/ employment. Regardless of the measure, however, there is no gainsaying that density fell markedly in the 1980s.

The secand problem in measuring union density relates to the membership statistics themselves. In the U.K. (and in Ireland) meabership data are cbtained from unions, which differ in their methods of counting: some unions include retirees, sane are slow to drap from their books workers who are unemployed and do not pay oues, scme have computerized data files while others 
do not, etc. (Walsh; Eurostat). In the U.K. some unions exaggerate membership to maintain a high profile on a national level, biasing upward the recorded density and potentially minimising declines in density. In Ireland the Registrar of Friendly societies abtains membership fram reoognised unions, some of whom report irregularly, and excludes other labor organizations, creating potential errors in the data though with no cbviaus bias in trends. ${ }^{3}$ These problens notwithstanding, we calallated densities from official membership figures from 1945 through the 1980s for both countries, and obtained the pattern shown in exhibit 1: increases in density in the U.K. in the late 1960s-1970s followed by sharp drops in the 1980 s and a grachal trend upward in Irish density. These patterns are the phencmenon of cancen to this paper. potential causes of change

One widely-cited cause for the drop in British density is the loss of manufacturing jobs that characterized the first Thatcher term in office. hilile the decreased share of employment in wanufacturing undoubtedly hurt unions, we reject this campositional change as a major cause of the turnaround an three grounds. First, because density fell within most sectors of the ecanamy, including heavy manufacturing (see exhibit 2). A shift-share aralysis shows that changes in industrial composition explains a bare 0.4 points of the 1980-1986 8.6 point drop in union density in exhibit $2 .^{4}$ second, because changes in the industry mix of employment were mo greater in the U.K. than in Ireland, where density did not fall..$^{5}$ Third, because the shift from manufacturing was only modestly larger in the 1980s than in the 1970 s when union density rose. 6

What about the increased share of employment amang historically weakly unionised female or white collar workers or among part-time workers? our 
analysis show that these changes are of insufficient magnitude to explain more than a slight proportion of the 1980s drop in density. In 1979 approximately 408 of women were in unions compared to 60 t of men (Price and Bain, p. 49). Between 1979 and 1986 the female share of enployment rose by 2.8 percentage points. Mutiplying the 1979 difference in male and female union densities by the 1979-86 change in the female share of employment yields an estimated drop in density of just 0.6 points. In addition, the female share of elployment rose more from 1972 to 1979 (3.3 points) whan density increased than from 1979 to 1986 when density fell $(2.8$ points). 7 The shift from mamal to namarual labor appears to be associated with a larger drop in union density. Acoording to the New Earnings Survey, the nomanual share of elployment grew by $47 \%$ to 554 of all employees from 1979 to 1987, (New Earnings survey, Summary Analyses, 1979, table 21 and 1987, table 36). Price and Bain estimate a difference in unian density between blue-collar and white-collar workers of 7 points in 1979; Millward and Stevens (1988) find a difference of 16 points in density between manual and normanul workers in the 1984 horkplace Industrial Relations Survey. Taking the larger of these estimates, the 8 point increase in the ramanual share of euployment can explain at most 1.3 points $(=.08 \times .16)$ of the decline in density in the period. Finally, data fram the British social Attitudes Survey shows a 1980-1985 drop in union density amang full-time workers of 4 points (Millward and stevens, 1988) compared to a drop for all workers of 4.5 points, indicating that increases in the share of part-timers had very little impact on overall density.

In sum, cantrary to the assessment of Towers (1989), we find that shifts of elployment from highly unionised to less unionised graps of workers were not the major cause of the 1980 s drop in unian density. If changes in 
incustry, gender, and collar of work were orthogonal, our calaulations imply that 3.1 percentage points of the 1980-86 drop in density is due to changes in the structural factors enmerated above - leaving 5.5 points or nearly 2/3rds of the observed change attributable to other factors. Since industry mix, collar of work, and gender are correlated, the proportion of change due to factors beyand changes in composition will in fact be higher, strengthening our conclusion.

Another possible cause for the drop is worsened public opinion of unions, which Iipset has proposed as an explanation for the U.S. drop, and which might be applicable to the U.K. After all, didn't anly 39 percent of unionists vote Labour in 1983? And didn't most citizens support the government in the Miners' strike? opinion poll evidence contravenes this explanation, revealing a rise in public approval of unions during the 1980s, perhaps due to the weakness of unions (Bassett; Edwards and Bain, 1988). In addition, in the 1970 s and 1980 s approval of unions was higher in the U.K. than in Canada, where density stabilised. 8

Business cycle developments, which are important determinants of union membership (Bain and Elshiekh; Carnuth and Disney; Booth, 2983), and wich grew less favourable to unions between the 1970 s and 1980s, offer a more plausible cause of falling British union density, but carnot by thenselves explain the 1970s-1980s turnaraind in union fortumes. Union density continued to fall through 1986 when the economy was on the upewing, and fell relative to Irish density (exhibit 1) despite the more severe downturn and more sluggish econamic recovery in Ireland. Consistent with these observations, Booth (1988) finds that a business cycle model fit through 1980 overpredicts British density in the 1980 s by an increasing amount each year, until by 1986 predicted density 
exceeds actual density by 7 percentage points. This implies that at most $30 \%$ of the 1981-1986 drop in density can be attributed to cyclical factors. 9

Samething more is evidently needed to explain the turnaraund in density.

orr mypothesis is that this "something more" is the legal enviranment for incustrial relations, as reflected in laws regulating union and management behavior in the area of union reocgnition and menbership. That this is plausible is indicated by the broad cancordance of the drop in density with the incustrial relations bills of 1980, 1982, and 1984, and by the continued rise of union density in Ireland where no axh legislation was enacted. To go beyand plausibility, however, it is necessary to determine how legislative changes affect density in a voluntaristic industrial relations system, and to control for other potential deteminants of density in a multivariate analysis. 2. Union Fomation, Density, and Industrial Pelations Iegislation

We analyse the effects of industrial relations legislation and other factors on unionism using a stock-flow model of density in which exogenous changes in the legal and economic erviraments affect flows into urianism, which produce ammlative impacts on stocks (Freenan, 1988). In such a model changes in density depend on union organisation of new plants, 'depreciation' of density due to changes in employment in existing workplaces, and the 'birth' of new nonmion plants. Formally, let ULeNs = union density; PCTNEN = the ratio of workers in newly recognised workplaces less derecognition of existing unions to total enployment; $r=$ the "normal" rate of change in union menbership due to changes in employment in arrently organized plants ( 200 when membership falls and $r<0$ when membership rises, so that it is the analogue of a depreciation rate); and $g=$ growth of enployment. Then density depends on the now of workers into unionism by: 10 
(1) ULONS $=[(1-r) /(1+g)] \operatorname{UdaNS}(-1)+\operatorname{PCINEN} /(1+g)$

1 (1-r-g) UDeNs $(-1)+(1-g)$ PCINEW,

where the "net depreciation" of density, $r+g$, is assumed to be small and positive (expansion of employment in union plants can make $r<0$, but $|r|$ is likely to be less than $g$ because $g$ depends not anly an growth of employment in existing nanmion plants but also on employment in new plants "born" nomunion).

The steady state density in equation (1) is PCINEW/(r+g), which directs attention at two determinants of change: the rate of new organisation of workers less de-recognition; and net depreciation. In the U.K. de-recognition appears to be of minor importance in the period studied Millward and Stevens, 1986, pp. 64-69), so that PCINEW will be largely determined by whether or not unians organize new workplaces. Changes in net depreciation, on the other hand, may also have contributed to the drop in unionism, as employment grew less in union than in nommion firms from 1980 to 1984, all else the same (Blanchflower and Oswald). As industrial relations laws are more likely to affect the rate of new organization than the rate of depreciation (which presumably depends largely on labour market forces), we consider next what determines the PCTNEN coupanent of equation (1).

determinants of new unian organisation

Although econamists often model unionisation as if it depended solely on workers' decisions, in actuality organising involves the behavior of: workers, who evaluate the benefits/oosts to them of unianising; Inians, who devote resources to organizing; and employers, who recognize unians or try to prevent organization. To assess the impact of industrial relations legislation on organising sucoess it is necessary to consider the interactions among these parties. Our model of organising, shown schematically in Exhibit 3, posits 
three basic relations linking their behavior:

1) A "prouction function" relating the number of workers newly organized to the resarros unions and workers devote to organizing; to the resources managenent epends opposing (favouring) union reoognition; and to other factors. The production of new members depends an national labour laws and institutions because those laws and institutional arrangenents make union organising resources and maragenent oposition less (more) productive. Even though organization and recognition is voluntaristic in the U.K. (73z of recognition of manual trade unions is by "discussion" and 168 by "extension" of existing relations (Daniel and Millward)), labour laws affect the organising process in several ways: through the legal options they offer employers to withhold recognition or to appose unians; through the options they give workers to join or not join unions, as in the closed shop; and through the ways they allow or disallow unions to pressure ellployers for reoognition (i.e. secondary boyootts). As for the impact of management opposition on unionisation, the abserved lower union density in plants that do not recognise unions than in plants that recognise unions (Dariel and Millward) certainly suggests that management can affect the ability of unions to enroll members.

2) The second relation links the resources management expends opposing unionisation of its work force to economic factors that influence the benefit/ cost calculus of aposition: the effect of unions on labour costs through the union wage premium; the cost of resisting unions at workplaces, which depends on legal options for opposition and penalties for unfair labaur practioes; and product market factors such as deregulation or foreign campetition that make anticipated unionisation more or less expensive to the firm; and union arganising activity. In the U.K. there is evidence that unionisation raises 
wages (Blanchflower and Oswald, 1988a) and reduces profitability (Bianchflaver and Oswald, 1988b; Machin), but no evidence that these effects have changed over time. Hence, increased aposition to unions from management is more likely to came from changes in the law that strengthen management's hand in aposing organisation than from changes in the economic cost of unions to firms. This is in contrast to the united states, where union wage premia rose in the 1970s, making unians more expensive to firms and contributing to the rise in management apposition (Freeman, 1986).

3) The third relationship in the model links union and worker organizing activity to the wage premium and other benefits unions win workers; to existing union density; to the resources management devotes to qposing unionism; and to a vector of econcmic factors such as rates of unelployment and inflation that might affect the desire for unionisation and organising activity over the long run as well as over the business cycle. In the U.K. the extent of trade union imminities from cammon law that makes industrial action a breach of cantract (see Nedderturn), will influence the strength of unions as organisations and the resources they have to devote to organisational calpaigns. The legality of the closed shop and the rights of workers to refrain fram menbership will also influence worker and union organising efforts.

Two features of the model deserve attention. First, the union wage premium (other gains that unions win for workers), often viewed as an incentive to unionise, has an indeterminate effect on organizing suocess. This is because the gains not only increase workers desire to unionise but also increase managenent oposition. ${ }^{11}$ An important implication is that industrial relations laws that affect union bargaining power, as ogposed to those that directly inpact organising, have ambiguaus impacts on density; a law which 
weakens unian bargaining power could increase organisation by increasing the willingness of management to recognise a union since the unian is likely to have a smaller adverse effect on profits. ${ }^{12}$ second, the interdependence of the resarroes each side allocates to the organising process and the posited illpact of past union density on urian activity can generate complex dymamic paths in arganizing sucoess and density. For instance, within a range, higher density will induce greater union organizing activity as the costs of organizing are spread over more union menbers, producing amulative changes in density, of the type abserved in many countries.

\section{British incustrial relations law}

In the United kingdom, the great difference in the relation and attitude of the two main political parties toward unions has produced major changes in inchustrial relations laws since the end of horld war II. The Labour Party extended the immmities given unions to conduct industrial disputes, supported the closed shop, and enacted laws to strengthen unions in negotiations; the Heath goverrment sought to moderate union strength with a more legalistic system; wile the Thatcher government enacted legislation designed to roll-back and limit union strength. Broadly, the laws have changed in three basic phases:

1946-1973, Labour laws grachally strengthen unionism. The Labour Party legislation included: the 1946 repeal of the Trade Disputes and Trade Unions Act of 1927 that had protected union menbers who refused to participate in industrial action, required "contracting in" for political funding, and forbade public authorities from demanding union menbership of their employees; the 1951 elimination of wartime limitations on strikes. The Conservative Party's 1971 Incustrial Relations Act created "unfair industrial practices", made collective agreements legally binding, enacted indivicual rights designed to weaken the closed shop, and introduced employee protections against unfair dismiseal. Wile unions opposed many of these provisions, they did nothing to weaken unioniem and, arguably, strengthened collective bargaining. 
1974-1979, Labour Party legislation substantially strengthens unionism. The Trade Union and Labour Relations Act of 1974 repealed the 1971 Act, restoring union immities wile keeping the protections against unfair dismissal. The Buployment Protection Act of 1975 provided positive rights to association; guaranteed rights to time off for union activity; strengthened the position of unions against employers in information disclosure, terms of employment, and rechmancies; and created the Advisory, conciliation and Arbitration Service and an arbitration mechaniem for failure to comply with its recomendations. The Trade Union and Labour Relations (Amendment) Act of 1976 extended union immunities.

1980-1988, Mrs. Thatcher's legislation shifted the legal balanoe against unions. The Buployment Act of 1980 limited picketing to a union's own place of work, placed restrictions on secondary industrial action, extended the permissible grounds for refusing to join a union in a closed shop setting, removed statutory calpulsory recognition procedures, and el iminated procectures allowing unions to call for arbitration when elployers underart agreed terms and conditions in a trade or industry. The 1982 moloyment Act eroded union imanities in the areas of inter-union dispartes, support strikes, and disputes not cancerned with narrowly-defined terms and canditions; prohibited "mion work only" contractual agreements; increased the compensation allowed to individuals dismissed owe to closed shop agreenents; required secret ballots for closed shops; and emhanced employer power to dismiss workers churing industrial disputes. The Trade Union Act of 1984 introduced liabilities for incustrial action not preceded by a favorable majority decision in a secret ballot of union memberahip, and required secret ballots for the election of executive comittees and for the continuation of political funding. Finally, though it extends beyand the period of our data, the moloyment hct of 1988 introduced liabilities for tnustees of union funds who endanger them by endorsing industrial action, removed immities for industrial action to enforce union memberahip, and gave union members the right to go to work despite a strike call, even where a majority of the menbership apported the strike in a secret ballot (see Tovers for a detailed discussion of the Thatcher government's legislation). 


\section{Irish industrial relations law}

In Ireland, where political parties do not divide sharply on trade unianism, the legal climate became gractually more favorable to unians curing most of the period under sturly. The biggest changes coaurred shortly after World war II. The 1946 Industrial Relations Act rewoved various wartime restrictions on unions, legalized strikes and restored the role of unions in bargaining for wage increases. The 1947 National Union of Railwaymen v. sullivan court decision abolished the Trade Union Tribunal that regulated union recruitment. Legislation in 1977 brought about a more modest improvenent in the position of unions: the Protection of Buployment Act established that no collective redundancies could take place abeent prior consultation among the enployer, unions, and the Minister for Labour, at least thirty days in advance of the event; and the Unfair Dismissals Act provided that all dismissals were to be regarded as unfair in disputes until justified by the employer. Finally, in 1982 the Trade Disputes (Amendment) Act extended the socpe of union immuities to all public sector unians, including those which had not been listed as "excepted bodies" under the provisions of the 1941 Trade Unian Act. indices of laws

To quantify the favorableness of the industrial relations laws in the U.K. and Ireland to unionism, we divided the laws into four categories and coded them using a 1-5 point scale, with a '5' for years when the law was most favorable to unions and a ' 1 ' when they were least favorable. Two of our categories relate to union organisation per se: employer recognition/unian bargaining rights and the individual rights of workers to associate or disassocinte from unians. The other two categories relate to the paver of unions and managenent in collective bargaining: immuities granted unians to 
engage in industrial dispoutes and regulations governing dismissal, arbitration, enployer provision of information, etc. We tried to scale the indices across time and between the countries in a consistent way so that one unit differences in the indices reflect roughly comparable differences in the laws. ${ }^{13}$ The resultant indices are given with a capsule explanation of the legal changes that motivated orr coding in Appendix A. A more detailed description of the laws and the rationale for our quantification is available to readers on request (Pelletier, 1989). The indioes show cansiderable changes in U.K. laws over time alang the lines indicated by arr earlier disassion: an improvement in the legal climate for unions fram the early 1940s to the 1970s, a marked change favourable to unionism in the seventies, followed by a sharp decline in the 1980s. Acoording to orr coding, the 1980s legal climate was similar in favourableness to the 1940 s climate. In Ireland, by contrast, the legal index rises gradually over time, with no 1980 s turnaround.

If our measures provide a reasanable ordinal rating of the legal climate for union organisation, density aght to grow more when the legal index is high than when it is low. In fact, this is the case (exhibit 4), with both British and Irish union density increasing more when the index is above than when it is below its average value, and with British density increasing relative to Irish density when British laws were relatively more favorable to unionism than were Irish laws. These patterns could, to be sure, reflect the influence of factors other than the laws, auch as changes in the state of the econouy, or in the party governing the country (Carruth and Disney, 1988). Even if valid, moreover, legislation-induced changes in density could be of lesser importance than those due to other factars. To assess the contribution of the laws to the 19808 drop in density, it is neoessary to imbed our indices in a ultivariate 
analysis that includes other determinants of unionism, to which we tum next.

\section{Esconametric Yodel}

Because we lack information on organizing activity and management resistanoe, we do not attenpt to estimate the structural equations of exhibit 3. Instead, we estimate recurod form equations that link union density to the Appendix A indices of the favourableness of industrial relations laws to unionisation, and use the model to interpret these equations. We obtain the reduced form equations by a two step procedure. First, we link the flow of new union mabers relative to the workforce to the legal enviranment and other potential determinants of worker, union, and management organising behavior and autcames. Let IAW = our index of laws; CYCIE = measures of business Cycle; $T D E=$ trend; $z=$ other factors that may influence unionism; and $u=$ error term with the standard properties. Then our reduced form organizing equation is:

(2) PCTNEN $=a$ LAN $+b$ CYCTE $+c$ TDE $+d$ UDENS $(-1)+e z+u$ Second, we substitute equation (2) into equation (1) to obtain an cbeervable relation between the explanatory variables and density:

(3) $\operatorname{DEN}=(1-\mathrm{r}+d)^{\prime} \operatorname{DONS}(-1)+a^{\prime} \operatorname{LAN}+b^{\prime} \operatorname{CYCIE}+c^{\prime} \operatorname{TDE}+e^{\prime} z+u^{\prime}$, where primes refer to parameters divided by $(1+g)$, to link current and lagged density properly.

The key variable in the aralysis is the legal index. While few will coject to our ordinal rating of the laws (surely 1982 British legislation was less favorable to unianiem than the 1978 legislation) same may object to our 15 scaling of the laws (why not 1-10 or 1-1000, etc?). One way of daaling with the scaling problem is to experiment with alternative measures or nonlinear functions of the laws. We have performed such experiments, with little impact an results. As our indices undoubtedly mismeasure the 'true' favarrableness of 
incustrial relations laws to unioniom our coding can be vied as introducing masurement ecorc that biases statistical results towand zero. To see which aspect of legal regulations affects dersity, we also record results in which we decampse our legal index into a subindex for laws that affect organising directly and those that affect union and managenent bargaining power.

our major cyclical variables are changes in retail prices and the level of unemployment. Analyses of cyclical determinants of unionisation (Bain and Elshiekh; Booth; Carruth and Disney) have used these and related variables (changes in elployment, changes in wage inflation, or in wage inflation less price inflation) to pick up the impact of the cycle on density. To measure the structural (and possbly cyclical) changes in the camposition of elployment that affect unionism, we use the manufacturing proportion of elployment and an independent trend term. Finally, to examine the possibility that our legal indices simply reflect which party cantrols parliament we also experiment with a chuny variable measuring wich party is in the majority. exonametric results

Exhibit 5 presents our basic regression results for the determinants of union density in the United Kingdan fran 1945 to 1986 . The dependent variable in these caloulations is the ratio of nembership to employment measured as in exhibit 1 in fractional units. Column 1 records the coefficients (and standard errors) for the estimated impact on density of aur legal index, a 0-1 dumny for Conservative cantrol of Parliament, trend, lagged density, and arrent values of cyclical variables. It shows that the legal index has a significant positive effect on density while the party controlling Parliament has no noticeable effect; that a greater manufacturing share of employment raises density; and that increases in inflation and unemployment raise density. The 
positive effect of unemployment on density, other factors fixed, differs fram the results of earlier studies that use different specifications, more complex lag structures, and time periods langer than ars, suggesting that its effect is particularly fragile and sensitive. ${ }^{14}$ As we are not conoerned with which cyclical variables reflect the effect of changing business canditions, we do not pursue this issue further.

Does the estimated .0023 coefficient ${ }^{15}$ on the legal index in column 1 imply that legal regulations are a major or minor determinant of U.K. density? In the short term, the effect of a one point change in the legal index on density is modest, inducing a change in density of just 0.23 percentage points in a given year. However, the 0.82 coefficient on the lagged dependent variable, however, tells us that the langrm impact of a one point change in the legal index (other variables) is much larger, inducing a massive 1.3 percentage point change $(=.0023 /(1-0.82))$. This suggests that changes in legal requlations are a major determinant of U.K. density over the lanamm.

colum 2 pursues our analysis by decamposing the legal index into its organising and collective bargaining capponents. Assuming we have correctly categorized the laws, the organizing subindex ought to have a greater effect on density than the collective bargaining camponent, as it directly affects PCIrEw in our model. In fact, colum 2 shows that the organising subindex has a positive significant effect on density wile the collective bargaining subindex has a virtally no impact. The 0.59 coefficient on the organising subindex implies that a unit change in this indicator of the legal erviromment alters unian density by 3.1 percentage points in the lang run $(=.0059 / 0.19)$. Because the organising subindex changes by much less than the total legal index (it drops by 3 points from 1979 to 1980 and by 2 points thereafter compared to a 6 
point drop in the total. index from 1979 to 1980 and a 7 point additional drop thereafter), however, the effect of changes in the organising subindex on density is quantitatively similar to that of the change in the total index. The larger coefficient on the organising subindex reflects the scaling of the variable rather than ary substantive difference in the respanse of density to a "camparable" change in it as in the total index.

column 3 and 4 present regressions that exploit the potential linkage between unmeasured determinants of unionisation in the U.K. and in Ireland. Here, we estimate union density equations for the two countries using a seemingly unrelated regression model that takes acoount of intercorrelations in disturbances between the countries. This model should increase the efficiency of our estimate of the impact of the U.K. legal index an density; and, more importantly, test the generality of arr approach by examining the effect of Irish industrial relations law on Irish density. The analyses in colume 3 and 4 differ in two additional ways from those in colums 1 and 2 . First, because arr Irish unionisation data only go thraugh 1984 column 3 and 4 are limited to 1945-1984 rather than extending through 1986. Second, because our analysis of the Irish data, Iike those of others (Sapsford 1984, Roche and Iarragy 1989) show that different cyclical variables affect Ireland and the U.K., changes in euployment enter as a cyclical variable in the Irish density equation but not in the U.K. density equation. 16

Turning to the reaults, the estimates in colum 3 confirm our major finding that U.K. industrial relations laws have a lange and significant effect on U.K. density, and show only marginal differences in coefficients from those in column 1. This is because the cross-equation correlation between the residuals from the U.K. and Irish density equations is just -.11, inplying that 
we did not onit any substantial common determinant of density fram our single equation analyses. The estimates in colum 4 reveal that Irish incustrial relations law has a sizeable but imprecisely estimated impact on Irish density. As Irish labour laws did not vary as much as the British labour laws, there is insufficient variation in the index to yield a statistically well-defined extimate, and the weak positive effect in colum 4 is about as strang a result as could be expected.

In addition to the calaulations in exhibit 5, we probed the statistical relation between U.K. union density and the indices of laws in several ways to see how robust our findings were to changes in model specification. In ane set of caloulations we dropped the insignificant chumy variable for conservative control of parliament and lagged the cyclical variables. The result was a modest drop in the magnitude of the coefficient on our legal index that still left a substantial and statistically significant effect for that variable. 17 In another set of calaulations we estimated arr model using an AR(1) structure. This also yielded substantial significant impacts for arr indices of labour laws. 18 In another set we added additional lagged union density terms, with little impact on our results. While it is always possible that in limited time series data same model specification might yield substantively different regression results, our finding that industrial relations laws affected union density in the U.K. is robust to these standard model modifications.

\section{canclusion}

To retarn to arr opening question, how wuch of the 1980 s drop in British trade union density can be attributed to the Thatcher government's industrial relations laws?

Perhaps the most insightful way to explore this question is to simulate 
what would have happened to density if the laws changad as shown by our legal index wille all other determinants of density ware constant. Bhibit 6 shows the results of such a simulation exercise. Colum 1 gives the change in the the index of labour relations laws in each year: it drops sharply in 1980, in 1982, and in 1985 with the industrial relations acts enacted in those years, and is zero otherwise. Dolum 2 estimates the effect of the legal changes on density in the same year: we obtain it by multiplying the change in the index by the .0023 estimated impact of the index on density. Colum 3 estimates the delayed effects of legal changes on aurent density through the effect of ane years' density on the next years' density: we obtain it by ulltiplying the previous years change in density that was caused by changes in the 1 legal index by the .82 coefficient on lagged density from arr model. Finally, colum 4 gives the end result of past and arrent changes in the legal index on density by suming colums 2 and 3 . The figures here show that the changes in U.K. labor law reduced union density by 1 to 1.7 percentage points per year from 1980 to 1986 . Amulating the armul changes, wind that the legal changes caused density to fall by 9.4 percentage points from 1980 to 1986 effectively the entire decline in U.X. density in that period.

An alternative way to use our estimated models to assess the impact of the legal changes on density is to forecast what would have happened to density had the laws remained unchanged in the 1980 s - that is, if the Labour Party legislation of 1976 remained in place - while all other variables took on their actanl values. Such a simulation projects a drop in density of 1 to 2 percentage points, depending on the specific model used.

Wile both of these "counter-factual exercises" are crude, and the precise nubers subject to the usual canfidenoe band around regression model estimates, 
the important point is that they tell the same story: that the vast bulk of the cheerved 1980:s decline in union density in the U.K. to the changed legel enviroment for industrial relations. The "something more" conitted from the usul cyclical models of U.K. Unian density appears to be the nation's labour laws, partioularly those relating to union organisation.

How lang and how extensive is the decline in British union density due to the 1980s legal changes likely to be in the futare? To answer this question we extended our simulation into the 1990s, and repart the results in the bottam half of exhibit 6 . Assuming that the 1988 change in labour laws remains in place and that there are no additional legal develquents, our model predicts U.K. density to fall at a rapidly diminishing rate until density stabilizes in the mid/late 1990 s at somentat below $40 \%$ of the workforce. Underlying this is our assessment of the 1988 Industrial Pelations Act, which we have coded as rectucing the favaurableness of U.K. labour laws to unioniem by 2 points compared to the 11 point recuction in the index brought about by preceding legislation. Of course, other factors will affect the path of density over time. The decreasing share of exployment in manufacturing, the rising share of wamen in the work force, and the angoing shift fram manual to narmanual labour will cantinue to reduce density, though presumbly at reduced rates as the relevant shares of employment stabilize. Comersely, new irrovations introduced by British unions for their menbers - credit cards and low mortgage rates for union menbers, for example (see Booth (1989) and Towers) - will act to maintain and possibly increase density. However, unless these programs are a great aucoess or Parliament passes legislation favarable to unions, it is diffialt to see any upowing in British union density in the near future. 
Exhibit 1: Irish and UK Union Density 1945-1986

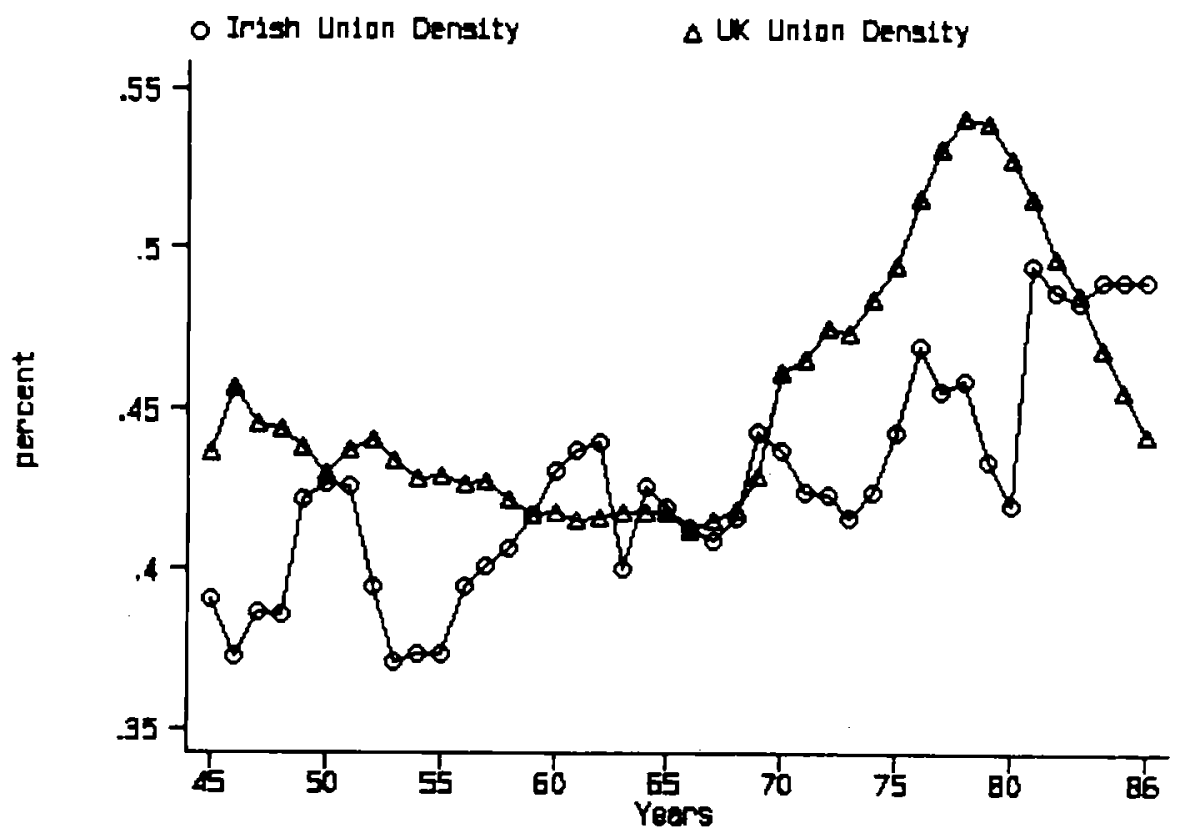


Exhibit 2: Estimates of Union Density and Changes in Density by Sector, 1980-1986:

Agriaultural (SIC 0)

A) Ag, for, \& fish.

Industrial Production (SIC 1-4) (total)

A) Energy, water, minerals \& ores, metals, chemicals, engireering, $\&$ vehicles.

B) Other mfg., incl. textiles, clothing, paper, printing, publishing,

Construction (SIC 5)

Services (SIC 6-9)

A) Distribution, hotels, catering, repairs

B) Transport \& comminication

C) Banking, finance, ins., business services, leasing

D) Public admin. and defence

E) Oth. services

(incl. education and medical)

Total $^{5}$
Menbership Employment Density

$\begin{array}{rrrrrrr}1980 & 1986 & 1980 & 1986 & 1980 & 1986 & \text { Gange } \\ 69 & 0^{1} & 361 & 310 & 19.1 & 0.0 & -19.1\end{array}$

$\begin{array}{lllllll}4282 & 2607 & 7360 & 5664 & 58.2 & 46.0 & -12.2\end{array}$

$\begin{array}{lllllll}3269 & 1972^{2} & 4630 & 3601 & 70.6 & 54.8 & -15.8\end{array}$

$\begin{array}{llllll}2147 & 1987 & 1543 & 1928 & 139.1^{3} & 103.1^{3}-36.0\end{array}$

$\begin{array}{rrrrrrr}1684 & 1645^{2} & 6070 & 4406 & 27.7 & 37.3 & +9.6^{4} \\ 12905 & 10539 & 22008 & 21088 & 58.6 & 50.0 & -8.6\end{array}$

800RCE: Departpent of Emplerment Gazette, May issues : 1980,86

Noter for Donjbit 2:

1 The National union of Apriaultural and Nllied Morkars and the Netional Unian

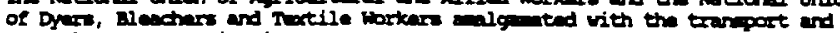
Generel bockare' union in $29 a 2$.

2

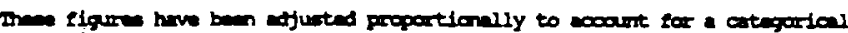

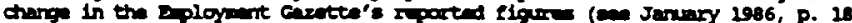
and ry $180 \mathrm{~s}$ P. 277 ).

3

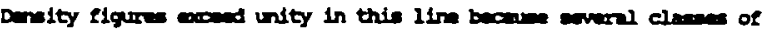

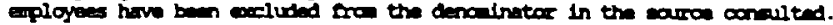

4

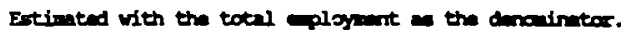

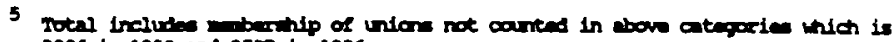
2806 in 1900 ind 2587 in 296. 
Exhibit 3: The Impact of Labour Laws Laws on Union Organizing Activities, Management opposition, and Unionisation of New Workers

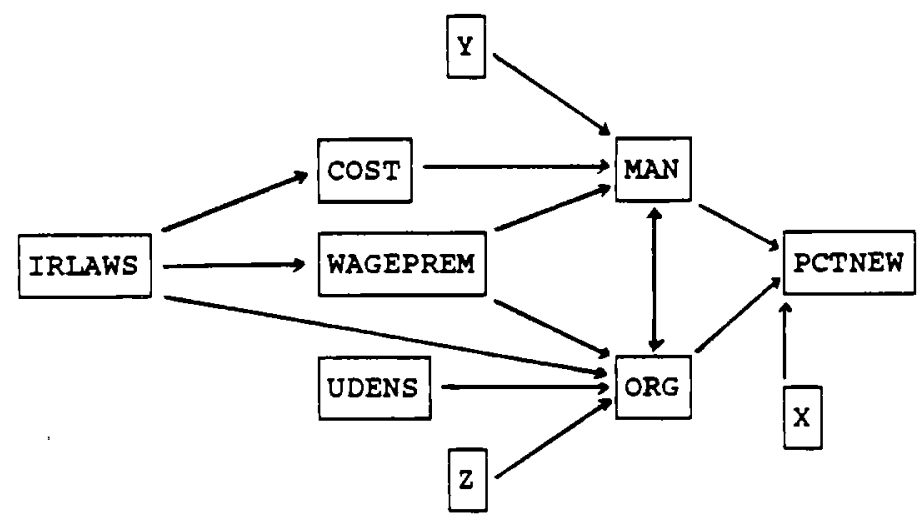

The first relation

Determination of organizing success: PCTNEW $=f(M A N, O R G, X$ ) where PCTNEW = number of workers organized/labor force : MAN = resources devoted by management to opposing unions; ORG = resources devoted by unions to organizing; $\mathrm{X}=$ other factors that influence outcomes

\section{The second relation}

Management opposition: MAN = g (WAGEPREM, COST, ORG, Y) where WAGEPREM - union wage premium; $\cos T=$ cost of opposing union $Y=$ other relevant factors, largely relating to product market factors such as deregulation of industries, etc., which determine effect of unionism on profitability.

The third relation

Union and worker organizing effort: ORG = h(WAGEPREM, MAN, UDENS, $z$ ) where UDENS = union density at the beginning of the period; $z=$ other relevant factors, largely relating to labor market

IRIAWS = Industrial Relations Laws that affect organisation and bargaining power of unions. 
Exhibit 4: Averoge Amual Changes in

Union Density (in percentage points)

1945-86

Lead hat Abow Avg Leged bed. Bdow Avg

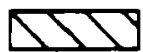

Change in Density

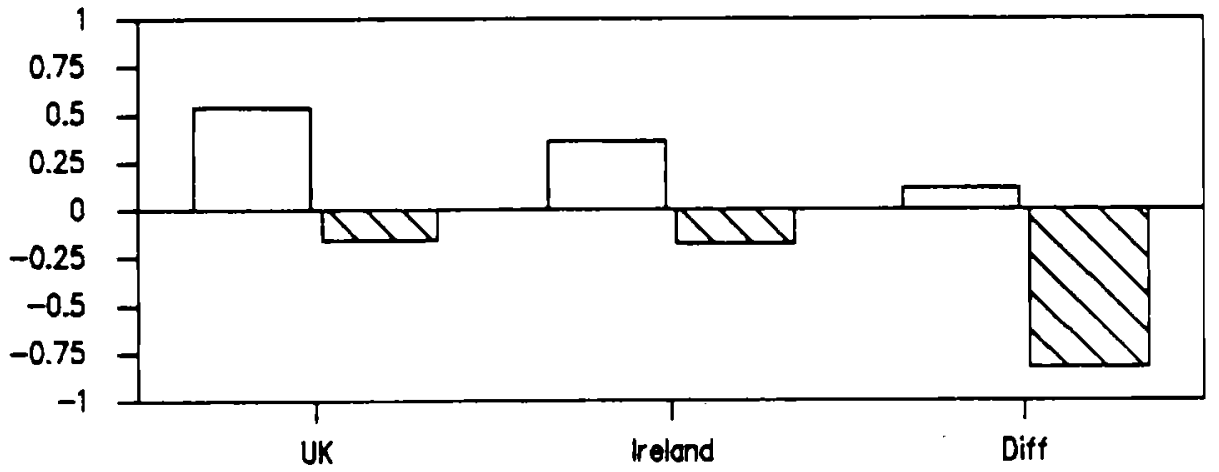

Note: 1945-84 for reland and for the ux-tedend Difference 
Exhibit 5: Regression Cofficients (Standand Broors) for the Effect of IR Iaws and other Factors on U.K. and Irish Density, 1945-86

\begin{tabular}{|c|c|c|}
\hline Regression No. & (1) & (2) \\
\hline Estimating Tech. ${ }^{1}$ & ors & Ors \\
\hline $\begin{array}{l}\text { Dependent } \\
\text { Variable: }\end{array}$ & $\begin{array}{c}\text { UK } \\
\text { Density }\end{array}$ & $\begin{array}{l}\text { UK } \\
\text { Densit }\end{array}$ \\
\hline \multicolumn{3}{|c|}{ Independent, Variables } \\
\hline $\begin{array}{l}\text { Iegal Index } \\
\text { Iegal subindices }\end{array}$ & $\begin{array}{l}.23 \\
(.08)\end{array}$ & - \\
\hline Organising & 一 & $\begin{array}{l}.59 \\
(.22)\end{array}$ \\
\hline Bargaining & 一 & $\begin{array}{l}-.02 \\
(.16)\end{array}$ \\
\hline $\begin{array}{l}\text { Conservative } \\
\text { Dummy }\end{array}$ & $\begin{array}{l}-.17 \\
(.29)\end{array}$ & $\begin{array}{l}.21 \\
(.35)\end{array}$ \\
\hline
\end{tabular}

$\begin{array}{lcccc}\text { Lagged Dependent } & .82 & .81 & .81 & .58 \\ \text { Variable } & (.07) & (.07) & (.07) & (.13) \\ \text { Trend }^{2} & .03 & .05 & .02 & .02 \\ & (.03) & (.03) & (.02) & (.05)\end{array}$

\begin{tabular}{|c|c|c|c|c|}
\hline $\begin{array}{l}\text { Mfg Share } \\
\text { of Employment }\end{array}$ &. .34 & $\begin{array}{l}.28 \\
(.15)\end{array}$ & $(.32)$ & $\stackrel{.34}{(.17)}$ \\
\hline $\begin{array}{l}\text { Iog change } \\
\text { retail prices }\end{array}$ & $\begin{array}{l}.07 \\
(.04)\end{array}$ & $\begin{array}{l}.06 \\
(.04)\end{array}$ & $\begin{array}{l}.07 \\
(.04)\end{array}$ & $\frac{.10}{(.06)}$ \\
\hline $\begin{array}{l}\text { Uneipoloyment } \\
\text { Rate }\end{array}$ & $\begin{array}{l}.28 \\
(.15)\end{array}$ & $\stackrel{.18}{(.14)}$ & $\begin{array}{l}.27 \\
(.14)\end{array}$ & $\begin{array}{l}.24 \\
(.12)\end{array}$ \\
\hline $\begin{array}{l}\text { Cange in } 10 g \\
\text { Employment }\end{array}$ & - & - & - & $\begin{array}{l}-.22 \\
(.06)\end{array}$ \\
\hline constant & $\begin{array}{l}-.08 \\
(.06)\end{array}$ & $\begin{array}{l}-.07 \\
(.06)\end{array}$ & $\begin{array}{l}-.07 \\
(.06)\end{array}$ & $\begin{array}{l}-.02 \\
(.09)\end{array}$ \\
\hline $\overrightarrow{\mathbf{R}}^{\mathbf{2}}$ & .969 & .986 & .968 & .807 \\
\hline SEE & .008 & .007 & .008 & .016 \\
\hline
\end{tabular}

Yotes:

$I_{\text {OIs }}$ is ordinary least equares; SUR is seemingly unrelated regression 2 coafficients on trend and legal index Iultiplied by 100 for ease of presentation.

3 Regressions in colum 4 uses independent variables for Ireland. 
Exhibit 6: Simulated Changes in Union Density due to cranges in U.K. Iabour Laus, 1980-1995

\begin{tabular}{|c|c|c|c|c|}
\hline \multirow[b]{2}{*}{ Year } & \multirow{2}{*}{$\begin{array}{l}\text { Change in } \\
\text { Ingal } \\
\text { Index } \\
\text { (1) }\end{array}$} & \multicolumn{3}{|c|}{ Change in Density one to: } \\
\hline & & $\begin{array}{l}\text { Arrent Change } \\
\text { in Index } \\
\text { (2) }\end{array}$ & $\begin{array}{l}\text { Previous Change } \\
\text { in Index } \\
\text { (3) }\end{array}$ & $\begin{array}{l}\text { arrent and Prev } \\
\text { crange in index }\end{array}$ \\
\hline $\begin{array}{l}1980 \\
1981 \\
1982 \\
1983 \\
1984 \\
1985 \\
1986\end{array}$ & $\begin{array}{r}-6 \\
0 \\
-3.5 \\
0 \\
-1.5 \\
0 \\
0\end{array}$ & $\begin{array}{r}-1.4 \\
0 \\
-0.8 \\
0 \\
-0.3 \\
0 \\
0\end{array}$ & $\begin{array}{l}-1.1 \\
-0.9 \\
-1.4 \\
-1.2 \\
-1.2 \\
-1.0\end{array}$ & $\begin{array}{l}-1.4 \\
-1.1 \\
-1.7 \\
-1.4 \\
-1.5 \\
-1.2 \\
-1.0\end{array}$ \\
\hline $\begin{array}{l}1987 \\
1988 \\
1989 \\
1990 \\
1991 \\
1992 \\
1993 \\
1994 \\
1995\end{array}$ & $\begin{array}{r}0 \\
-2 \\
0 \\
0 \\
0 \\
0 \\
0 \\
0 \\
0\end{array}$ & $\begin{array}{r}0 \\
-0.4 \\
0 \\
0 \\
0 \\
0 \\
0 \\
0 \\
0\end{array}$ & $\begin{array}{l}-0.8 \\
-0.7 \\
-0.9 \\
-0.7 \\
-0.6 \\
-0.5 \\
-0.4 \\
-0.3 \\
-0.2\end{array}$ & $\begin{array}{r}-0.8 \\
-1.1 \\
-0.9 \\
-0.7 \\
-0.6 \\
-0.5 \\
-0.4 \\
-0.3 \\
-0.2\end{array}$ \\
\hline
\end{tabular}

Saurce:

Column 1: Obtained as the change in the legal index in the year from Appendix A.

Colum 2: Obtained as .0023 times the colum 1, were .0023 is the estimated effect of a unit change in the legal index from column 1 of exhibit 5 .

Colum 3: Abtained as .82 times the change in density in colum 4 in the previous year, where .82 is the estimated effect of lagged density an current density fram colum 1, exhibit 5

colum 4: sum of colums 2 and 3. 


\section{ENDNOTES}

1. When we tabulate union membership from the British Social Attitudes 1987 survey we find that 11 of the unemployed are union members compared to 418 of the employed.

2. These figures are from Kelly, table 2, page 10.

3. The published Irish series show different numbers of unions responding in different years, with modest differences in membership, implying that it is the smaller unions that may not report each year. Statistics compiled by the Registrar of Friendly Societies exclude membership of unions that choose not to register; those listed as excepted bodies under the provisions of the act; and, most importantly, unions based in other countries ( $i$. e. the U.K.), which may account for as much as 15 of Irish union membership; See Walsh, pp. $29-31$ and Roche and Larragy for a detailed discussion of the Irish data.

4. We obtained this estimate by calculating a predicted union density from the following equation: PUDENS ${ }_{1986}-w_{19861}$ UDENS $_{1980,1}$ and comparing it to the actual density.

5. In both the U.K. and Ireland, the manufacturing share of employment fell by 6 points in the 1980 s, according to OECD figures.

6. From 1974 to 1980 the manufacturing share of employment in the U.K. fell by 4.2 points, compared to 5.7 points fron 1980 to 1986.

7. Alternative data on union density by sex are available for 1981 from the Department of Employment Gazete. We do not compare female and male densities over time because the Gazette reports in May 1988 that "1t is no longer possible to produce useful comparisons of male and female membership with previous years as there is a lack of consistency in their provision of this information" ( $p .276$ ).

8. Gallup poll data shows the proportion of the British public viewing unions as a "good thing" to range between 50 and 70 percent while table 6 in Chaisan and Rose shows that the proportion of Canadians approving of unions varied from 40 to 60 percent in the 1970 s and 1980 s.

9. This is based on figures from Booth (1989), table 1.

10. The growth of employment term, $g$, enters because the base of current density is current employment while the base of lagged density and new members is last period's employment.

11. This suggests one explanation of the Disney and Mudambi finding that an index of the union wage gap has a parabolic relation to union membership, conditional on past membership: at modest union wage effects, worker and union organizing activicy may increase more than management resistance, but when effects are large the converse may be true, so that "excessive" union wage gains reduce density. 
12. If laws weaken union bargaining power to the point where unions have essentially no impact on outcomes, they are almost certain to reduce organizing activity and new unionization because some return is needed to start the unionisation process going.

13. To minimize potential errors in our coding, we asked Professor Paul Weiler of the Harvard Law School to review our codes, and our final rating reflects his Input as well.

14. Carruth and Disney find that changes in unemployment have a negative effect on union membership (as opposed to density) while the acceleration or deceleration of changes in unemployment has a positive effect. Summing up their coefficient estimates on the various unemployment rates suggests a -.03 effect for current unemployment, a -.02 offect for lagged unemployment, and a .05 effect for unemployment lagged two periods. Booth (1980) finds a negative effect for current unemployment and a postive effect for lagged unemployment, of comparable magnitude. Nelther of these studies included the highly cyclical manufacturing share of employment as an independent variable, as we did.

15. This finding may reflect errors in the employment series, about which is not as high quality as the series for the U.K. Errors in employment will induce a negative relation between changes in employment and density, since an especially high (low) employment figure will reduce (increase) density in a given year and cause a large (small) increase in employment. 


\section{BIRITOCRNFAX}

Bain, George Sayers, and Farouk Elsheikh. Union Growth and the Business gycle: an Foonometric Analysis. (Oxford: Basil Blackiell, 1976).

Bain, George Sayers, and Robert Price. "Union Growth: Dimensions, Determinants, and Destiny." In G.S. Bain, ed., Inoustrial Relations

in Britain. (Oxford: Basil Blackwell, 1983).

Bain, T. Wnions and Industrial Pelations in Great Britain in the Past Ten Years", Bulletin of Camparative Iabour Relations, Number 16, $1987,27-58$.

Bassett, Fhilip. "Unions popular as membership falls." Financial Times Nov. 18, 1987.

Blanchflower, D. and Cowald, A "Profit-Pelated Pay: Prose Discovered" Econcmic Journal 98 November 1988, pp 720-730.

Blanchflower, D. and Oswald, A "The Economic Effects of Trade Unions" Exployment Insitute Econanic Report vol 3, no 10 September 1988

Booth, Alison. "A Reconsideration of Trade Union Growth in the United Kingdom." British Journal of Industrial Relations. Nov.1983: Vol 21: pp. 379-393.

Booth, Alison. "What Do Unions Do Now?" mimso Kassachusetts Institure of Technology, March 1989

Canuth, Alan, and Richard Disney. Where Have Two Millian Trade Union Members Gone?" Econamica (Feburary 1988), 1-19.

Chaison, Gary N. and Joseph Rose "Oontinental Divide: the Direction and Fate of North American Unions" Mavaster University Working Paper 309, sept 1988

Clark, Jon, and Lord Wedderburn. "Juridification - A Universal Trend? The British Experience in Labor Law." offprint fran Guther Teubner, ed. , Juridification of Social Spheres, Burpean University Institute, Florence. Series A: Law.6. (Berlin: Walter de Guyter, 1987).

Crouch, Colin. "Conservative Industrial Pelations Policy: Towards Labour Exclusion?" in otto Jacobi et al., eds. Eoonamic crisis, Trade Unions and the State. (Iandan: Croan Helm, 1986).

Daniel, w.W. and Neil Millward, Wordolace Industrial Relations in Britain (Lomian:Heineman, 1983).

Department of Bmployment, Dmployment Gazette, Membership in Trade Unions", May editions, various years 
Disney, R. and Mdambi, R Modelling Trade Union Membership: theory and evidence for the UK, 1953-1985" Mimeo University of Kent

Danovan. Royal Camission on Trade Unians and Employers' Associations. Beport. Onnd 3623. (Landon: Hiso, 1968).

Edwards, P.K. and Bain, G.S. Why are Trade Unions Becoming Hore Popular? Unions and Public opinion in Britain" Britich Jammal of Industrial Belations, November 1988, 311-326.

Frealan, Richard B. "Cantraction and Expansion: the Divergence of Private Sector and Public sector Unionism in the United States" Jourmal of Banomic Perspective, vol 2 number 2, Spring 1988, PP 63-88.

Freeman, Richard B. "The Effect of the Union Wage Differential on Management Opposition and Union Organizing Sucoess" American Fonomic Review, May 1986, pp 92-96.

Freeman, Richard B. and James L. Medoff. What Do Unions Do? (New York: Basic Books, 1984).

Gallacher, Michael. Political Parties in the Republic of Ireland. (Manchester: Manchester University Press, 1985).

Hernandez, Mary T. "Union Growth and Govermment Policy in the United Kingdom." Harvard University Senior Thesis (1985).

House of Camons (United Kingdam). 1988 Employment Bill [Bill 17]. (Iandan: MYSO).

Hyman, Richard. "Trade Unians: Structure, Policies, and Politics". In G.S. Bain, ed., Industrial Relations in Britain. (Oxford: Basil Blackiell, 1983).

Kelly, John. "The Measurenent and Maaning of Trade Union Density." mimeo from the Department of Industrial Relations, Landon School of Ecanamics. (Sept. 1987).

Kerr, Tany, and Cerry hyte. Irich Trede Union Ixw. (Professional Books Itd., 1985).

Lewis, Roy. "Oollective Labour Law." in George Sayers Bain, ed. Industrial Relations in Britain. (Oxford: Basil Bladowell, 1983).

Lipset, Seymour Martin "Labor Unions in the Public Mind" in S.M. Lipset (ed.) Unions in Transition (San Francisco: Institute for Contemporary Studies 1986, 287-321

Machin, S.J. Wunions and the Capture of Economic Rents: an investigation using British Finm Level Data" mimeo Department of Econcmics, University College Iandon October 1988

Mocarthy, Charles. Trede Unions in Ireland: 1894-1960. (Dublin: Institute 
Public Administration, 1977).

Millward, Neil and Mark Stevens. British Workolace Incustrial Relations 1980-1984 (Landan, Gower, 1986)

Millward, Neil and Mark Stevens. "Union Density in the Regions" in Department of Employment, Employment Gazette, May 1988, 286-295

Nevin, Danald, ed. Trade Unions and Change in Irish Society. (Dublin: The Nercier Press, 1980).

O'Hara, Bernard J. The Evolution of Irish Inoustrial Relations Iaw and Practice. (Dublin: Folens, 1981).

Pelletier, Jeffrey. "The Evolution of Industrial Relations Legislation in the UK and Ireland". mimeo, Harvard University, Karch 1989.

Price, R. and Bain, G.S. "Union Growth in Britain: Retrospect and Prospect" The British Jarnal of Industrial Relations, 1983,46-68

Prondzynski, Ferdinand von. Employment Law. (Ferdinand Maxwell, 1984).

Roche, W.K. and Joe Larragy. "The Trend of Unianisation in the Republic of Ireland." in T. Murphy et al., eds. , Becent Trends in Irich Industrial Relations: A Reader. (Dublin: UCD, 1987).

Roche, w.K. and Joe Iarragy. MThe Determinants of the Amual Rate of Trade Union Growth and Decline in the Irish Republic: Evidence fram the DUES membership series." (Dublin: UCD, 1989)

Sapsford, David R. "The Determinants of Trade Union Growth in the Irish Republic: An Econometric Study." Eoonamic and Social Review,Vol.15:4, p. 305-323 (1984).

Sapsford, David R. Trade Unions: Some Econonic Aspects of Their Behavior with Particular Reference to the Republic of Ireland. (Dublin: The Ecancmic and Social Research Institure, 1984a).

Simitis, Spiros. "Juridification of Labor Relations." abridged version of: "Zur Verrechtlichung der Arbeitsbeziehumgen." in H. Zacher, S. Simitis, F. Kubler, K. Hopt and G. Teubner, eds., Verrechtlichung von Wirschaft, Arbeit und sozialer solidaritat - Verqleichende.

Anvlyzes. (Baden - Baden: Nomos, 1984)

Towers, B. "Rurming the Gauntlet: British Trade Unions under Thatcher, 1979-1988" Industrial and Labor Relations Revien Jan 1989, 163-187

Walch, Kemeth. "The Measurement of Trade Union Nembership in Ireland and the UK." Industrial Relations Jaumal. Vol.16:1, pp.25-33, 1985.

Wedderturn, Iord. The Worker and the Law Harmansworth: Penguin 
Appendix A: DNICES OF DNDUSTRIAL REIATIONS LANS:

Here we present a summary of the four features of industrial relations law under cansidaration, and the numerical scores we gave to each. Columns A through D show the ratings given for each year and each category, as described at the right of the table. The total legal indices are presented under the column marked 'total.' The index for onganizing is the sum of columns A and B; the index for collective bargaining power is the sem of column C and D.

$\mathbf{A}=$ recognition/bargaining rights $\quad B=$ individual rights to associate/dissociate C = immities

$D$ = relative pover of employers/unions

\section{UNTIED knEDar}

\begin{tabular}{rrrrrr} 
Year & A & B & C & D & Total \\
\hline 1941 & 4 & 2 & 1 & 2 & 9
\end{tabular}

$\begin{array}{lllllr}1942-45 & 4 & 2 & 1 & 2 & 9 \\ 1946 & 4 & 3 & 1 & 3 & 11 \\ 1947-50 & 4 & 3 & 1 & 3 & 11 \\ 1951 & 3 & 3 & 3 & 3 & 12\end{array}$

$\begin{array}{llllll}1952-63 & 3 & 3 & 3 & 3 & 12 \\ 1964 & 3 & 3 & 2 & 3 & 11 \\ 1965 & 3 & 3 & 3 & 3 & 12 \\ 1966-68 & 3 & 3 & 3 & 3 & 12 \\ 1969 & 4 & 3 & 3 & 3 & 13\end{array}$

$\begin{array}{llllll}1970-71 & 4 & 3 & 3 & 3 & 13 \\ 1972 & 4 & 2 & 2 & 4 & 12\end{array}$

vajor legal changes

A: Order $1305(1940)$. compulsory arbitration procedures and official encouregenent of reoognition.

B: Trede Dicantes and Thede Unions Act (1927). (1) public authorities forbidden to demand union meiberahip of employees.; (2) "oontracting in" substituted for "contrecting art."

c: Order $1305(1940)$, general ban on strikes and lockats in effect.

D: TD/TUA (1927). protection for individuals refusing to participate in industrial action

B \& D: TD/TA (1927) is repealed.

A \& C: Order 1376 (1951), legalized strikes by eliminating Order 1305: set framework for bargaining and conflict, but abstained from regulation.

C: Bockes v Barmand decision (1964), reestablished trade union liability to the tort of "intimidation."

C: Trade Disputes Act (1965), trade unians given statatory immity against the tort of "intimidation."

A: Comission on Industrial Relations (est 1969); volumtary machinery to make recommendations on recognition issues (in respanse to report of Danovan Comission (1968) and white paper "In Place of Strife").

A: CIR enters compulsory phase; little change in climate for recognition 
1973

1974

42

2

12

1975

$5 \quad 5 \quad 4$

5

19

$\begin{array}{llllll}1976 & 5 & 5 & 5 & 5 & 20 \\ 1977-79 & 5 & 5 & 5 & 5 & 20 \\ 1980 & 3 & 4 & 3 & 4 & 14\end{array}$

1981

3

1982
14

10.5 Pyoleyment Act of 1982 .
B: Industrial Relations Act (1971) comes into effect. Introduced indivichal legal rights aimed at weakening trade union organization and the closed shop (rights not to belang).

c: IRA (1971). Civil liabilities called unfair industrial practices" introduced; collective agreements legally made

binding.

D: IRA (1971), established first substantial set of elployee protections against unfair diemissal to be enacted in U.K. Labor law.

B \& C: Trade Union and Labarr Relations Act (1974). repealed IRA (1971): immities are restored;

D: protections against unfair dismissal are re-enacted.

A: Duployment protection Act (2975). creation of ACAS and compulsory recognition procedures; unions given right to refer recognition issues to ACAS; arbitration mechanism provided for failure to comply.

B: BPA (1975) provided positive rights to associate; guaranteed right to time off for union activity.

D: ERA (1975), strengthened position of unions against enployers with respect to terms of elployment, information disclosure, and recimdancies.

c: Trade Union and Iabour Pelations (Amendment) Act (1976), Extersion of immities spelled art in TURA (1974).

Pmployment Act of 1980 .

A: statutary reoognition procectures established by the EPA (1975) abolished; non-ompulsory procedures restored. B: extension of permissible grounds to refuse to join a union in a closed shop setting; funding for pre-strike ballots. c: picketing limited to am place of work; restriction on "secandary industrial action."

$D$ : abolished procedures allowing unions to call for arbitration where enployers were underautting agreed terms and canditions in a trade or industry. 
A: prohibited contractual arrangement or industrial action ensuring that contracts go anly to enployers with reoognized trade unions.

B: compensation increased for indiviauls dismissed due to closed shop agreenents; secret ballots required for continuation of closed shops. c: removed imminities from industrial action regarding intermion disputes, support strikes dispurtes of international origin, and those not cancerned with narcowly-defined terms and conditions. D: enhanoed elployer power to dismiss specific workers during disputes.

Trade Union Act of 1984 .

B: secret ballots required for election of exeartive coumittees, industrial action, and contimution of political funding (no change in index). c: liabilities introduced for industrial action not preceded by a favarable majority decision by secret ballot of union memberahip.

D: employer powar strengthened by ability to seek injunctions against unions encouraging euployees to

Diployment Act of 1988.

C: removed immities for industrial action related to the employment of nan-unionists; liabilities introduced for trustees of union funds. D: extension of individual rights to act against union (incl. right to go to work despite a strike call). 
IREIAND

\begin{tabular}{llllll} 
Year & A & B & C & D & Total \\
\hline 1941 & 2.5 & 3 & 1 & 3 & 9.5
\end{tabular}

Major lecal changes

A: Trede Union Act (1941), established

licensing requirements for the acquisition of bargaining rights.

B: IUA (2941), established the Trade Union tribumal for the purpose of regulating recowitment efforts of trade unions. Citizens allowed to join only the unions prescribed by the Tribumal for their workplace.

C: leges standstill order (1941). declared all forms of industrial action to be illegal (iseaved under Energency Powers Act of 1939).

TIA (1942). linited imminities of 1906 Act to authorized trade unions and

1942-45

$\begin{array}{llll}2.5 & 3 & 1 & 3\end{array}$

9.5

1946

$\begin{array}{llll}2.5 & 3 & 3 & 3\end{array}$

11.5

1947

$$
\begin{array}{llll}
2.5 & 5 & 3 & 3
\end{array}
$$

1948-65

1966

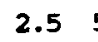

2.5

3

3

13.5

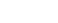

1967-68

1969

1970

1971

1972-76

1977

$\begin{array}{ll}2.5 & 5 \\ 2.5 & 5 \\ 2.5 & 5 \\ 2 & 5\end{array}$

13

13.5

13

13

14
13.5 $\begin{array}{lll}2 & 5 & 3\end{array}$

$\begin{array}{llll}2 & 5 & 3 & 4\end{array}$

$\begin{array}{llllll}1978-81 & 2 & 5 & 3 & 4 & 14 \\ 1982 & 2 & 5 & 4 & 4 & 15\end{array}$

excepted bodies anly.

C: IRA (1946). removed ban on strikes impoeed by the 1941 order.

D: Industrial Relations Act (1946). removed government wages controls imposed by Wages Standstill onder (licencing requirenents remain).

B: N.U.R. v sullivan decision, abolished trade union tribumal as unoanstiturional; right to form and join trode unions (Carstitution 1937) restored to full force.

c: Electricity (Special Provisions) Act (1966). Criminal sanctions for picketing imposed on certain public sector unions (limited in scope).

C: E(SP)A (1966) is repealed.

A: Trade Union Act (1971) increased requirements for obtaining negotiation licenses.

D: Fuployment protection Act (1977). limited employer power to create collective redundancies.

Unfair Dismigsals Act (1977). required employers to justify dismissals in unfair dismiseal disputes (rather than employee justification of unfair dismiseal).

C: Trade Disputes (Amendment) Act (1982) extended scope of trade unian immities to include all public service unions. 
ENDNOTES

1. When we tabulate union membership from the British Social Attitudes 1987 survey we find that 118 of the unemployed are unian menbers caupared to 418 of the enployed.

2. These figures are from Kelly, table 2, page 10.

3. The published Irish series show different numbers of unians respanding in different years, with modest differenoes in membership, implying that it is the smaller unions that may not report each year. Statistics compiled by the Registrar of Friendly societies exclude menbership of unions that choose not to register; those listed as excepted bodies under the provisions of the act; and, most importantly, unions based in other countries (i. e. the U.K.), which may acount for as much as 15t of Irish union memberghip; See Walsh, pp. 29-31 and Roche and Larragy for a detailed discussion of the Irish data.

4. We obtained this estimate by calculating a predicted union density from the following equation: PUDONS $2986=$ (W $_{1986 j}$ UDNS 1980 , and comparing it to the actual density. our result 196 consistent with 1989 ith and Disney's finding that uses a similar but more disaggregated shift-share analysis of the effects of changing incustry mix on density.

5. In both the U.K. and Ireland, the manufacturing share of employment fell by 6 points in the 1980s, according to ODC figures.

6. Fram 1974 to 1980 the manufacturing share of employment in the U.K. fell by 4.2 points, calpared to 5.7 points from 1980 to 1986.

7. Alternative data on union density by sex are available for 1981 fram the Department of Employment Gazette. We do not compare female and male densities over time because the Gazette reparts in Yay 1988 that "it is no longer possible to produce useful cuparisons of male and female memberahip with previous years as there is a lack of consistency in their provision of this information" (p. 276).

8. Gallup poll data shows the propartion of the British public viewing unions as a "good thing" to range between 50 and 70 percent while table 6 in Craisan and Rose shows that the proportion of Canadians approving of unions varied from 40 to 60 percent in the 1970 s and 1980s.

9. This is based on figures from Booth (1989), table 1.

10. The growth of eiployment term, $g$, enters because the base of current density is arrent employment wile the base of lagged density and new menbers is last period's eiployment.

11. This aggests one explanation of the Dianey and yudami finding that an index of the union rage gap has a parabolic relation to union membersinip, conditional on past mambership: at modest union wage effects, wocker and union organizing activity may increase more than management resistanoe, but when effects are large the corverse may be true, so that "excossive" union wage gains reduce density. 
12. If laws waken union bargaining power to the point where unions have essentially no impact on artocmes, they are almost certain to reduce organizing activity and new unionization because some return is needed to start the unionisation process going.

13. To minimize potential errors in orr ooding, we asked Professor Paul Weiler of the Harvard Law school to review arr codes, and arr final rating reflects his input as well.

14. Carruth and Disney find that changes in unelloloyment have a negative effect on union membership (as oposed to density) while the acoleration or deceleration of changes in unelployment has a positive affect. Suming up their coefficient estimates on the various unaploymant rates suggasts a -.03 effect for current unemployment, a -.02 effect for lagged unemployment, and $a .05$ affect for unewployment lagged two pariods. Booth (1980) finds a negative effect for ourrent unemployment and a portive offect for lagged unemployment, of comparable magnitude. Neither of these studies included the highly cyclical manufacturing share of employment as an independent variable, as we did.

15. Note that table gives the actual coeficient multiplied by 100 for ease of presentation.

16. This finding may reflect errors in the employment series, about which is not as high quality as the series for the U.K. Errors in employment will induce a negative relation between changes in employment and density, since an especially high (low) employment figure will rechoe (increase) density in a given year and cause a large (small) increase in employment.

17. The coefficient on the legal index was .18 with a standard arror of .07 when we lagged the $10 \mathrm{~g}$ change in retail prices and the unemployment rate. In this case the lagged density term remained at 0.82 so that the estimated langterm impact of a percentage point change in density was 1.0 compared to the 1.28 in colum 1 of exhibit 5 .

18. In this case the estimated coefficient on the legal index had a coefficient of .18 with a standard error of .07 The estimated autocorralation parameter was -.21 with a standard error of .18 wile the coefficient on laggad density was 0.84 with a standard error of .06 . The lang term effect of a ane point change in the legal index is thus 1.13, modestly emaller than the 1.28 in colum 1 of exhibit 5. 